\title{
Production of Thymineless Mutants in Gram-Negative Bacteria (Aerobacter, Proteus)
}

\author{
By J. T. SMITH \\ Department of Bacteriology, Guy's Hospital Medical School, \\ London, S.E. 1
}

(Accepted for publication 22 November 1966)

\begin{abstract}
SUMMARY
Conditions necessary for the production of thymineless mutants in Gramnegative bacteria by aminopterin treatment were examined. Although Escherichia coli and Proteus strains were readily made 'thymineless' (i.e. requiring added thymine) no such mutants were obtained with the majority of Aerobacter strains. However, two methods which produced thymineless mutants in all the Aerobacter strains were found; these were: treatment with alkaline EDTA before, or temperature shift down during, incubation with aminopterin. In every case where temperature shift alone resulted in the production of thymineless mutants more were found when it was used in conjunction with EDTA pretreatment. It was also found that the phase and size of inoculum, the method used to sterilize aminopterin and the concentration of thymine in the plating media had profound effects on the production and detection of thymineless mutants.
\end{abstract}

\section{INTRODUCTION}

Compared with the other nuclear bases thymine is unique in that it is found in DNA but not in RNA; hence thymineless mutants (i.e. requiring added thymine for growth) have proved to be valuable in the study of bacterial DNA. Thymine starvation of such mutants can lead to 'thymineless death' (Barner \& Cohen, 1954), the cause of which is not completely known. In other cases thymine deficiency in culture media for thymineless mutants has been shown to induce mutations (Coughlin \& Adelberg, 1956) lysogenic bacteriophage (Korn \& Weissbach, 1962) colicin production (Sicard, 1961) and premature initiation of the DNA-replication cycle (Pritchard \& Lark, 1964). The elimination of 'curing' of extrachromosomal elements from thymineless mutants has been demonstrated under conditions of thymine deprivation (Clowes, Moody \& Pritchard, 1965) for sex (F) and various colicin ( $\mathrm{col}$ ) factors. Most of these studies have been made on thymineless mutants of Escherichia coli which were produced by suitable aminopterin treatment (Okada, Yanagisawa \& Ryan, 1961; Clowes et al. 1965). During a study of resistance transfer (RT) factors in various species of Gramnegative bacteria it was considered necessary to examine their elimination. Acridine treatment has been shown to eliminate RT factors readily from Shigella and Escherichia (Watanabe \& Fukasawa, 1961) but Clowes et al. (1965) showed that it did not eliminate certain col factors which could be removed by thymine deprivation of thymineless mutants of $E$. coli. These authors concluded that thymine deprivation seems to differentiate factors which cannot be eliminated and are integrated in the chromo- 
some, for example, the $\mathrm{F}$ factor in $\mathrm{Hfr}$ (high frequency of recombination) strains, from those which are extrachromosomal and are eliminated, for example, the $F$ factor in $\mathrm{F}^{+}$strains.

\section{METHODS}

Organisms. The following strains were used: Aerobacter cloacae 53, A. aerogenes 418 and 373 and Escherichia coli 419 (Smith \& Hamilton-Miller, 1963) and Aerobacter (Klebsiella) aerogenes 43, 414 and 415, Proteus morganii 185 and P. rettgeri 410 (Hamilton-Miller, Smith \& Knox, 1965). Escherichia coli $\mathrm{K} 12$ met $^{-}$was supplied by Professor W. Hayes, E. coli 114 was a strain isolated post mortem.

Media. Davis Mingioli (DM) medium was used throughout this work (Davis \& Mingioli, 1950). The mineral salts solution and the glucose solution were sterilized separately by autoclaving $\left(115^{\circ}\right.$ for $10 \mathrm{~min}$.). Solid $\mathrm{DM}$ medium was made by mixing $50 \mathrm{ml}$. cold double strength DM medium with $1.5 \mathrm{~g}$ agar in $40 \mathrm{ml}$. water which had been melted by autoclaving, and other additions or $10 \mathrm{ml}$. water were added before the plates were poured. The only organism which required a supplement was Escherichia coli $\mathrm{K} 12$, and when this strain was examined L-methionine at $20 \mu \mathrm{g}$. $/ \mathrm{ml}$. was used.

Reagents. Thymine and aminopterin were obtained from L. Light and Co. Ltd., Colnbrook, Bucks. Thymine was made up as a $2 \mathrm{mg} . / \mathrm{ml}$. solution in distilled water and sterilized by autoclaving. Aminopterin was initially sterilized by autoclaving, but in later experiments it was dissolved in sterile double strength DM medium, then thymine and water added and sterilization effected by filtration through a no. 5 sintered glass filter. Sterility tests were always done.

Method for production of thymineless mutants. Details of the experimental procedures used are given for each experiment under the appropriate tables.

Estimation of reversion rates to thymine independence. Cultures of thymineless mutants of each organism were grown overnight in DM medium containing $80 \mu \mathrm{g}$. thymine $/ \mathrm{ml}$.; $1.0 \mathrm{ml}$. was spread on $10 \mathrm{DM}$ agar plates without added thymine and incubated overnight. Serial decimal dilutions made in DM buffer containing $80 \mu \mathrm{g}$. thymine/ml. were also counted on DM agar containing $80 \mu \mathrm{g}$. thymine $/ \mathrm{ml}$. From the counts obtained on DM medium without added thymine the number of revertants $/ \mathrm{ml}$. was obtained. This was used to calculate the frequency of reversion per bacterium growing on DM agar containing $80 \mu \mathrm{g}$. thymine $/ \mathrm{ml}$.

\section{RESULTS}

Aerobacter cloacae 53 was incubated for 2 days at $37^{\circ}$ in $0.8 \mathrm{~mm}$-aminopterin +200 $\mu \mathrm{g}$. thymine/ml. in DM medium and examined for thymineless mutants; none was obtained (limit of detection $0.2 \%$ ). Higher concentrations of aminopterin up to $2 \mathrm{mM}$ were tested in four experiments without success. Escherichia coli organisms are generally impermeable to charged molecules for which there is no transport system, but it has been shown that EDTA treatment increases their penetration (Leive, 1965). The effect of EDTA on the production of thymineless mutants by growth in aminopterin was therefore examined. An $18 \mathrm{hr}$ culture of $A$. cloacae 53 was diluted $10^{-4}$ in $0.05 \mathrm{M}-$ phosphate buffer ( $\mathrm{pH} 8$ ) containing mM-EDTA and incubated for $15 \mathrm{~min}$. at $37^{\circ}$ (EDTA pretreatment). The bacteria were then diluted $1 / 10$ into DM medium containing $0.8 \mathrm{~mm}$-aminopterin $+200 \mu \mathrm{g}$. thymine $/ \mathrm{ml}$., incubated for 2 days at $37^{\circ}$ and 
varying dilutions plated on DM agar containing $200 \mu \mathrm{g}$. thymine $/ \mathrm{ml}$. After overnight incubation those plates which showed discrete colonies were then examined for thymineless mutants by replication to DM agar without added thymine; a low proportion $(0.83 \%)$ of these was obtained.

These mutants were taken and investigated to check what concentration of thymine was required for survival. It was found (Table 1) that in liquid media large inocula survived better than small inocula in any one concentration of thymine. Presumably organisms of the large inocula did so because of redistribution of excess intracellular thymine, whereas this thymine was diluted out in small inocula.

Table 1. Effect of inoculum size on thymineless death of a thymineless mutant of Aerobacter cloacae 53 in various sub-optimal concentrations of thymine

A thymineless mutant of Aerobacter cloacae 53 was grown overnight in DM medium containing $200 \mu \mathrm{g}$. thymine $/ \mathrm{ml}$. and various dilutions in DM medium containing different concentrations of thymine made. After incubation at $37^{\circ}$ for $6 \mathrm{hr}$ each culture was counted on DM agar containing $200 \mu \mathrm{g}$. thymine $/ \mathrm{ml}$.

\begin{tabular}{|c|c|c|c|c|}
\hline \multirow{2}{*}{$\begin{array}{l}\text { Inoculum } \\
\text { (bacteria/ml.) }\end{array}$} & \multicolumn{4}{|c|}{ Concentration of thymine ( $\mu \mathrm{g} . / \mathrm{ml}$.) } \\
\hline & 10 & $\stackrel{5}{\text { Survival (\%) }}$ & $2 \cdot 5$ & $1 \cdot 25$ \\
\hline $\begin{array}{l}7 \times 10^{6} \\
7 \times 10^{4} \\
7 \times 10^{2}\end{array}$ & $\begin{array}{r}>100^{*} \\
69 \cdot 4 \\
37 \cdot 5\end{array}$ & $\begin{array}{c}>100 \dagger \\
<.3 \\
<2\end{array}$ & $\begin{aligned} 34.7 \\
2.8 \\
<2\end{aligned}$ & $\begin{aligned} & 2.8 \\
& 0.8 \\
< & 2\end{aligned}$ \\
\hline & Multiplied & $\dagger$ Multiplie & 6-fold. & \\
\hline
\end{tabular}

Table 2. Effect of thymine concentration in plating media on detection of thymineless mutants of Aerobacter cloacae 53

Cultures in DM medium of Aerobacter cloacae 53 and a thymineless mutant of the same strain were mixed. Viable counts were made before mixing. From these counts the content of thymineless mutants in the mixture was $23.2 \%$. Dilutions were spread on various concentrations of thymine in DM agar and incubated overnight. Plates showing discrete colonies were taken and replicated on the same concentration of thymine and on to plates without thymine and the number of mutants scored after overnight incubation.

$\begin{array}{ccc}\begin{array}{c}\text { Concentration } \\ \text { of thymine } \\ (\mu \mathrm{g} . / \mathrm{ml})\end{array} & \begin{array}{c}\text { Thymineless } \\ \text { mutants } \\ \text { detected }(\%)\end{array} & \begin{array}{c}\text { Proportion of } \\ \text { thymineless } \\ \text { mutants } \\ \text { recovered }\end{array} \\ 30 & 22.8 & 0.98 \\ 50 & 24 \cdot 3 & 1.05 \\ 100 & 12.5 & 0.54 \\ 150 & 8 \cdot 3 & 0.36 \\ 200 & 6.1 & 0.26\end{array}$

The need for thymine in solid media was examined; it was found that $30 \mu \mathrm{g}$. thymine $/ \mathrm{ml}$. was the optimum whereas with 15 to $25 \mu \mathrm{g}$. thymine $/ \mathrm{ml}$. the colonies were smaller and no growth at all occurred at $10 \mu \mathrm{g} . / \mathrm{ml}$. As the optimum concentration of thymine was $30 \mu \mathrm{g} . / \mathrm{ml}$. it seemed possible that the $200 \mu \mathrm{g}$. thymine $/ \mathrm{ml}$. used in the solid media in the production of thymineless Aerobacter cloacae 53 mutants may have decreased the degree of their detection. To test this, wild-type bacteria were mixed 
with thymineless bacteria in a ratio of $3: 1$ and plated on various concentrations of thymine. After incubation overnight each plate was replicated on to a plate containing the same amount of thymine as well as to a plate without thymine and the number of thymineless mutants scored. The results (Table 2) showed that concentrations of thymine above $50 \mu \mathrm{g}$. $/ \mathrm{ml}$. allowed some mutant clones to grow when replicated on to DM medium without thymine and at $200 \mu \mathrm{g} . / \mathrm{ml}$. only about $25 \%$ of the thymineless mutants were detected. Thus in all subsequent experiments $30 \mu \mathrm{g}$. thymine $/ \mathrm{ml}$. was used in the solid media to prevent thymineless mutants from escaping detection; also $30 \mu \mathrm{g}$. thymine $/ \mathrm{ml}$. was included in the diluent to prevent thymineless death.

The phase of growth, the dilution of the inoculum, the method of sterilization of the reagents and the effect of EDTA pretreatment in the production of thymineless mutants of Aerobacter cloacae 53 were then examined. No mutants were detected in any experiment where EDTA pretreatment was omitted. The results of the EDTA pretreatment series (Table 3 ) showed that autoclaving $\left(115^{\circ}\right.$ for $10 \mathrm{~min}$.) decreased the activity of aminopterin as compared with filtration. The results also showed that when bacteria in the logarithmic phase were used as inoculum more mutants were obtained than when stationary phase bacteria were used. Furthermore, the inoculum size was important: the smaller the inoculum the greater the proportion of thymineless mutants obtained. Since all cultures reached about $2 \times 10^{8}$ bacteria $/ \mathrm{ml}$. it seems that many generations in the presence of aminopterin were necessary before an organism mutated to thymineless.

\section{Table 3. Effect of age, size of inoculum, and method of sterilization of amino- pterin on the production of thymineless mutants of Aerobacter cloacae 53}

A $3 \mathrm{hr}$ and an $18 \mathrm{hr}$ culture of Aerobacter cloacae 53 in DM medium were suitably diluted into $0.05 \mathrm{M}$-phosphate buffer (pH 8.0) with and without mM-EDTA and incubated at $37^{\circ}$ for $15 \mathrm{~min}$. then diluted into DM medium containing $0.8 \mathrm{mM}$-aminopterin and $200 \mu \mathrm{g}$. thymine/ml. The experiment was done in duplicate with either filter-sterilized or autoclaved aminopterin solution. Incubation in aminopterin + thymine in DM medium was made for 2 days at $37^{\circ}$ before plating on to DM agar containing $30 \mu \mathrm{g}$. thymine/ml. and screening for thymineless mutants by replication on to DM agar with and without $30 \mu \mathrm{g}$. thymine $/ \mathrm{ml}$. The results with EDTA pretreated bacteria only are shown since no mutant was detected where pretreatment was done in phosphate buffer only. Limit of detection, $0.5 \%$.

\begin{tabular}{|c|c|c|c|}
\hline & & $\begin{array}{l}\text { Approxin } \\
\text { (viable }\end{array}$ & $\begin{array}{l}\text { oculum } \\
\text { a/ml.) }\end{array}$ \\
\hline of organisms inoculat & $\begin{array}{l}\text { Method used to sterilize } \\
\text { aminopterin solution }\end{array}$ & $\begin{array}{l}10^{3} \\
\text { Thy } \\
\text { mut }\end{array}$ & $\begin{array}{l}10^{5} \\
\text { ss } \\
\text { \%) }\end{array}$ \\
\hline Stationary (18 hr culture) & $\begin{array}{l}\text { Autoclaving } \\
\text { filtration }\end{array}$ & $\begin{array}{r}4 \cdot 3 \\
22 \cdot 1\end{array}$ & $\begin{array}{l}0 \\
0\end{array}$ \\
\hline Logarithmic ( $3 \mathrm{hr}$ culture) & $\begin{array}{l}\text { Autoclaving } \\
\text { filtration }\end{array}$ & $\begin{array}{l}12 \cdot 3 \\
80 \cdot 2\end{array}$ & $\begin{array}{l}0 \\
0 \cdot 7\end{array}$ \\
\hline
\end{tabular}

The effect of incubation temperature without the use of EDTA pretreatment was examined by using small inocula of logarithmic-phase Aerobacter cloacae 53 organisms and filter-sterilized aminopterin solutions. Ten incubation temperatures between $23^{\circ}$ and $41^{\circ}$ were tested but no thymineless mutants were found. However, during these experiments a sample of culture incubated at $37^{\circ}$ on the first day was re-incubated at $35^{\circ}$ on the second day by mistake and in this case $76.7 \%$ of the bacteria were found to be thymineless mutants. Therefore the effect of temperature shift was investigated. 
The results (Table 4) showed that decreasing the incubation temperature from $37^{\circ}$ to $35^{\circ}$ after the first day produced a large proportion of thymineless mutants, whereas any larger decrease of incubation temperature decreased the number of mutants and any increase in incubation temperature gave no mutants at all. The growth rates of Aerobacter cloacae 53 and a thymineless mutant of the same strain in DM medium containing $200 \mu \mathrm{g}$. thymine $/ \mathrm{ml}$. were investigated at $37^{\circ}$ and $35^{\circ}$. The generation time of the parent strain was increased from $78 \mathrm{~min}$. at $37^{\circ}$ to $83 \mathrm{~min}$. at $35^{\circ}$, whereas the generation time of the thymineless mutant was decreased from $84 \mathrm{~min}$. at $37^{\circ}$ to 79 min. at $35^{\circ}$. Thus the multiplication of the thymineless mutant was somewhat temperature-sensitive as compared with that of the wild type. Incubation with aminopterin for 2 days at $37^{\circ}$ or $35^{\circ}$ did not give any thymineless mutants, whereas incubation at $37^{\circ}$ for the first day and $35^{\circ}$ for the second day did produce thymineless mutants. Therefore it seems that an incubation temperature of $37^{\circ}$ is essential to promote the formation of thymineless mutants which, once formed multiply more rapidly at $35^{\circ}$ and hence can be detected in significant amounts.

\section{Table 4. Effect of incubation temperature on the production of thymineless mutants of Aerobacter cloacae 53}

A $3 \mathrm{hr}$ culture of Aerobacter cloacae 53 in DM medium was diluted $10^{-4}$ into $0.05 \mathrm{M}$ phosphate buffer ( $\mathrm{pH} 8.0$ ), incubated for $15 \mathrm{~min}$. at $37^{\circ}$, then diluted $1 / 10$ into $\mathrm{DM}$ medium containing $0.8 \mathrm{~mm}$-aminopterin $+200 \mu \mathrm{g}$. thymine $/ \mathrm{ml}$. This was incubated for 2 days at various temperatures, diluted in DM medium containing $30 \mu \mathrm{g}$. thymine $/ \mathrm{ml}$. and plated on DM agar containing $30 \mu \mathrm{g}$. thymine $/ \mathrm{ml}$. and incubated overnight. Plates containing discrete colonies were replicated on to $30 \mu \mathrm{g}$. thymine $/ \mathrm{ml}$. and $0 \mu \mathrm{g}$. thymine $/ \mathrm{ml}$. DM agar, incubated overnight and the number of thymineless mutants scored. Limit of detection, $0.5 \%$.

$\begin{array}{ccc}\text { Incubation temperature }\left({ }^{\circ} \mathrm{C} .\right) & \begin{array}{c}\text { Thymineless } \\ \text { mutants } \\ \text { observed } \\ (\%)\end{array} \\ 37 & \text { Second day } & \\ 37 & 35 & 81 \cdot 2 \\ 37 & 33 & 71 \cdot 0 \\ 35 & 31 & 0 \\ 35 & 37 & 0 \\ 33 & 37 & 0 \\ 31 & 37 & 0 \\ & 37 & 0\end{array}$

Thus two systems were found which produced thymineless mutants of Aerobacter cloacae 53, both these methods were tested separately and in combination in the same experiment. The results (Table 5, top line) showed that either method increased the proportion of thymineless mutants to about the same extent and that both methods used together gave a still larger proportion of thymineless mutants $(94 \%)$. The method was therefore applied to other species of Gram-negative bacteria with the results shown in Table 5. These methods (EDTA pretreatment and temperature shift down) decreased the proportion of thymineless mutants for Escherichia coli and Proteus species, but all the Aerobacter strains tested were made thymineless more readily. Indeed with 4 out of 6 of the Aerobacter strains examined no mutants were detected by straightforward aminopterin treatment even though concentrations up to $2 \mathrm{mM}$ were tested. However, the use of EDTA pretreatment and/or temperature shift induced thymineless mutants in all these previously refractory Aerobacter strains, although 
with two of these strains temperature shift did not produce thymineless mutants. EDTA pretreatment was the most consistent method in the production of thymineless mutants in the Aerobacter strains, and in every case where temperature shift down alone resulted in thymineless mutants more were found when temperature shift down was used after EDTA pretreatment.

Table 5. Effect of temperature shift and EDTA pretreatment on the production of thymineless mutants in various species of Gram-negative bacteria

Three-hour cultures in DM medium were pretreated in $0.05 \mathrm{M}$-phosphate buffer (pH 8.0) or in mM-EDTA in phosphate buffer and diluted 1/10 at an inoculum size of about $10^{3}$ bacteria/ml. into DM medium containing $200 \mu \mathrm{g}$. thymine $/ \mathrm{ml}$. and various concentrations of aminopterin. After incubation for 2 days at the temperatures indicated the cultures were screened for thymineless mutants by plating on DM agar + thymine ( $30 \mu \mathrm{g}$. $/ \mathrm{ml}$. for all strains except Proteus strains where $80 \mu \mathrm{g}$. $/ \mathrm{ml}$. was used) and replica plating on DM agar with and without thymine. Limit of detection, $0.5 \%$.

\begin{tabular}{|c|c|c|c|c|c|c|}
\hline \multirow{3}{*}{ 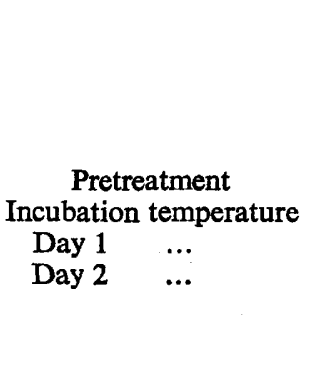 } & \multicolumn{4}{|c|}{ Pretreatment } & \multirow[b]{3}{*}{$\begin{array}{l}\text { Concentration } \\
\text { of } \\
\text { aminopterin } \\
\text { used (mM) }\end{array}$} & \multirow[b]{3}{*}{$\begin{array}{c}\text { Reversion } \\
\text { rate per } \\
\text { bacterium } \\
\text { per division }\end{array}$} \\
\hline & \multicolumn{2}{|c|}{$\begin{array}{l}\text { Phosphate } \\
\text { buffer } \\
\text { only }\end{array}$} & \multicolumn{2}{|c|}{$\begin{array}{l}\text { mM-EDTA } \\
\text { in } \\
\text { phosphate } \\
\text { buffer }\end{array}$} & & \\
\hline & $\begin{array}{c}37^{\circ} \\
37^{\circ} \\
\text { Thy }\end{array}$ & $\begin{array}{c}37^{\circ} \\
35^{\circ} \\
\text { minel } \\
\text { obta }\end{array}$ & $\begin{array}{l}37^{\circ} \\
37^{\circ} \\
\text { s mut } \\
\text { ed (\% }\end{array}$ & $\begin{array}{l}37^{\circ} \\
35^{\circ} \\
\text { nts }\end{array}$ & & \\
\hline Aerobacter cloacae 53 & 0 & 87 & 87 & 94 & 0.8 & $<1.5 \times 10^{-9}$ \\
\hline A. aerogenes 43 & $\begin{array}{l}0 \\
0 \\
0\end{array}$ & $\begin{array}{l}0 \\
0 \\
0\end{array}$ & $\begin{array}{l}0 \\
6 \\
3\end{array}$ & $\begin{array}{l}0 \\
0 \\
0\end{array}$ & $\begin{array}{l}0.8 \\
1.6 \\
2.0\end{array}$ & $9.1 \times 10^{-6}$ \\
\hline A. aerogenes 373 & $\begin{array}{l}0 \\
0\end{array}$ & $\begin{array}{l}\mathbf{0} \\
\mathbf{0}\end{array}$ & $\begin{array}{l}4 \\
0\end{array}$ & $\begin{array}{l}0 \\
0\end{array}$ & $\begin{array}{l}0.8 \\
1.6\end{array}$ & $2.0 \times 10^{-8}$ \\
\hline $\begin{array}{l}\text { A. aerogenes } 414 \\
\text { A. aerogenes } 415 \\
\text { A. aerogenes } 418\end{array}$ & $\begin{array}{r}18 \\
10 \\
0\end{array}$ & $\begin{array}{r}36 \\
19 \\
6\end{array}$ & $\begin{array}{r}15 \\
32 \\
0\end{array}$ & $\begin{array}{l}98 \\
74 \\
92\end{array}$ & $\begin{array}{l}0.8 \\
0.8 \\
0.8\end{array}$ & $\begin{array}{r}1.4 \times 10^{-5} \\
9 \cdot 1 \times 10^{-6} \\
<9.1 \times 10^{-10}\end{array}$ \\
\hline $\begin{array}{l}\text { Escherichia coli } 114 \\
\text { E. coli } 419 \\
\text { E. coli } \mathrm{K} 12\end{array}$ & $\begin{array}{r}97 \\
6 \\
99\end{array}$ & $\begin{array}{r}28 \\
4 \\
96\end{array}$ & $\begin{array}{l}0 \\
8 \\
2\end{array}$ & $\begin{array}{r}0 \\
0 \\
53\end{array}$ & $\begin{array}{l}0 \cdot 8 \\
0 \cdot 8 \\
0 \cdot 8\end{array}$ & $\begin{array}{r}<1.4 \times 10^{-9} \\
\quad 4.2 \times 10^{-8} \\
<4.0 \times 10^{-8}\end{array}$ \\
\hline $\begin{array}{l}\text { Proteus morganii } 185 \\
\text { P. rettgeri } 410\end{array}$ & $\begin{array}{l}100 \\
100\end{array}$ & $\begin{array}{r}33 \\
0\end{array}$ & $\begin{array}{l}0 \\
0\end{array}$ & $\begin{array}{l}0 \\
0\end{array}$ & $\begin{array}{l}0.8 \\
0.8\end{array}$ & $\begin{array}{l}1.2 \times 10^{-7} \\
1.1 \times 10^{-6}\end{array}$ \\
\hline
\end{tabular}

\section{CONCLUSIONS}

The data presented above indicate that optimum conditions for the selection of thymineless mutants in Aerobacter species include: aminopterin should be sterilized by filtration; organisms in the logarithmic phase should be used in small inocula of about $10^{3} / \mathrm{ml}$; thymine near the optimal concentration for growth of thymineless mutants should be used in the plating medium since higher concentrations can decrease the sensitivity of their detection. With the Aerobacter and Escherichia coli strains studied this concentration was about $30 \mu \mathrm{g}$. thymine/ml.; however, the Proteus species required $75 \mu \mathrm{g} . / \mathrm{ml}$. Nevertheless, with these improved conditions the Aero- 
bacter strains were more refractory to aminopterin treatment than were the $E$. coli or Proteus strains as regards the production of thymineless mutants. However EDTA pretreatment before and temperature shift down during aminopterin treatment induced the production of thymineless mutants in all the Aerobacter strains. It is interesting to note that with $A$. aerogenes 43 and 373 increase in aminopterin concentration alone did not result in the production of thymineless mutants whereas EDTA pretreatment at a lower concentration did produce mutants. Thus the effect of EDTA was not a simple one since it did not seem to work solely by increasing the effective intracellular concentration of aminopterin. The resistance of mammalian cells to amethopterin is not due to lack of permeability but seems to be due to higher intracellular concentrations of folic acid reductase which firmly binds the drug (Hakala, 1965). Perhaps, since EDTA increases the permeability of Gram-negative bacteria (Leive, 1965), it may potentiate the effect of aminopterin by causing the bacteria to lose factors like folic acid reductase which would normally block the mutagenic action of aminopterin.

Grateful thanks are due to W. J. Gunthorpe and Miss R. J. Anstey for expert technical assistance and to Professor R. Knox for reading the manuscript.

\section{REFERENCES}

BARner, H. E. \& CoHEN, S.S. (1954). The induction of thymine synthesis by T2 infection of a thymine requiring mutant of Escherichia coli. J. Bact. 68, 80.

Clowes, R. C., Moody, E. E. M. \& Pritchard, R. H. (1965). The elimination of extrachromosomal elements in thymineless strains of Escherichia coli $\mathrm{k} 12$. Genet. Res. 6, 147.

Coughis, C. A. \& AdelBerg, E. A. (1956). Bacterial mutation induced by thymine starvation. Nature, Lond. 178, 531.

Davis, B. D. \& MinGioli, E. S. (1950). Mutants of Escherichia coli requiring methionine or vitamin B 12. J. Bact. 60, 17.

HAKALA, M. T. (1965). On the role of drug penetration in amethopterin resistance of sarcoma-180 cells in vitro. Biochim. biophys. Acta $102,198$.

Hamlton-Miller, J. M. T., Smith, J. T. \& KNOX, R. (1965). Interaction of cephaloridine with penicillinase-producing Gram-negative bacteria. Nature, Lond. 208, 235.

KORN, D. \& WeIsSBACH, A. (1962). Thymineless induction in Escherichia coli $\mathrm{x} 12(\lambda)$. Biochim. biophys. Acta 61, 775 .

LEIVE, L. (1965). A nonspecific increase in permeability in Escherichia coli produced by EDTA. Proc. natn. Acad. Sci., U.S.A. 53, 745.

OKaDA, T., YANAGISAWA, K. \& RYAN, F. J. (1961). A method for securing thymineless mutants from strains of $E$. coli. $Z$. VererbLehre $92,403$.

PrITChaRd, R. H. \& LARK, K. G. (1964). Induction of replication by thymine starvation at the chromosome origin in Escherichia coli. J. molec. Biol. 9, 288.

SiCARD, N. (1961). Microbial physiology. Role of macromolecular synthesis on the viability of Escherichia coli 15 T- and E. coli 15 T-H-. C. r. hebd. Séanc. Soc. Biol., Paris 252, 617.

SMith, J. T. \& HAMilton-MilleR, J. M. T. (1963). Differences between penicillinases from Grampositive and Gram-negative bacteria. Nature, Lond. 197, 976.

Watanabe, T. \& FuKasawa, T. (1961). Episome-mediated transfer of drug resistance in Enterobacteriaceae. II. Elimination of resistance factors with acridine dyes. J. Bact. 81, 679. 